\begin{tabular}{|l|l|}
\hline Research Article & Open Access \\
\hline
\end{tabular}

\author{
국내에 자생하는 한국잔디 종자의 변이 특성 \\ 배은지 ${ }^{1 *} \cdot$ 이광수 $^{1} \cdot$ 박용배 $^{1} \cdot$ 김동수 $^{1} \cdot$ 양근모 $^{2}$ \\ 국립산림과학원 남부산림자원연구소 ${ }^{1}$, 단국대학교 녹지조경학과 ${ }^{2}$
}

\title{
Characteristics of Seed Variation of Zoysiagrasses (Zoysia spp.) Native to South Korea
}

\author{
Eun-Ji Bae ${ }^{1 *}$, Kwang-Soo Lee ${ }^{1}$, Yong-Bae Park ${ }^{1}$, Dong-Soo Kim ${ }^{1}$, and Geun-Mo Yang ${ }^{2}$ \\ ${ }^{1}$ Southern Forest Resources Research Center, Korea Forest Research Institute, Jinju, 600-300, Korea \\ ${ }^{2}$ Department of Green Landscape Architecture Science, Dankook Univ., Cheonan, 330-714, Korea \\ (Received on August 30, 2013; Revised on September 15, 2013; Accepted on September 22, 2013)
}

\begin{abstract}
In this study, 241 zoysiagrasses (Zoysia spp.) accessions naturally growing in South Korea were collected in order to investigate the seed morphological traits. One of the goals of this study was to identify the morphological characteristics and variations of zoysiagrass seed. For the 241 zoysiagrasses accessions collected, a total of $41 \%$ (99 accessions) was interspecific hybrid zoysia, which showed various types of seed variations different from zoysiagrass species. Most of these hybrids zoysiagrasses were classified into Z. sinica type and Z. japonica type. Group I and II included Z. sinica type, this group showed 30.1 and 17.5 in number of seed per spike and 4.6 and $5.2 \mathrm{~mm}$ in seed length. Group III and IV included Z. japonica type, this group showed 59.2 and 45.8 in number of seed per spike and 3.3 and $3.4 \mathrm{~mm}$ in seed length. There is a need for additional research on growth characteristics and the molecular level for the interspecific hybridization which confirmed that genetic variation from level of gene flow between the species.
\end{abstract}

Key words: Hybrid, Interspecific hybridization, Variation, Zoysiagrass

\section{서 론}

한국잔디는 화본과의 Zoysia속에 속해 있으며, 필리핀, 태국을 비롯한 동남아시아의 열대 지역부터 한국, 일본, 중국 등 동북아시아의 온대 기후 전역에 걸쳐 분포하고 있다(Engelke et al., 1983). 세계적으로 한국잔디류에는 10 개 종이 있으며, 국내에는 들잔디(Zoysia japonica Steud.), 갯잔디(Z. sinica Hance.), 왕잔디(Z. machrostachya Franch. and Sav.), 금잔디(Z. matrella [L.] Merr.)가 자생하는 것으 로 보고되고 있다(Choi, 1997; Choi et al., 1997).

Yu et al. (1974)은 우리나라에 자생하고 있는 잔디종류로 서 들잔디, 비단잔디, 금잔디 3군으로 구별하였다. Choi et al. (1997)은 국내에 자생하는 한국잔디 종은 들잔디, 금잔 디, 갯잔디, 왕잔디형이 관찰되었고, 이들 내에서 중간적인 형태특성을 보이는 교잡종과 변이종이 존재한다고 보고하

*Corresponding author:

Phone) +82-55-760-5026, Fax) +82-55-759-8432

E-mail)gosorock@korea.com
고 있다. 한국잔디의 형태적 조사 결과 지역에 따라 그 형 태에 있어서 많은 변이를 나타내었다(Bae et al., 2010).

한국잔디의 타가수분율은 약 $11-49 \%$ 로 자가수정 및 타 가수정에 의하여 모두 종자가 발생하여 종내 뿐만 아니라 종간에도 교잡이 가능한 것으로 알려져 왔다(Choi et al., 2008; Engelke and Murray, 1989; Hong and Yeam, 1985). 이와 같은 Zoysia속에 속하는 종들은 근연종간에도 형태 적으로 매우 비슷하며 식별이 어렵고, 종간교잡능력이 있 기 때문에 상호교잡이 용이하여 종간 및 종내 변이가 심 하게 나타나 한국잔디의 분류가 어려운 것으로 보고되어 있다(Hong and Yeam, 1985). 환경의 자생력과 적응력이 우수한 한국잔디의 여러 잡종형태의 생태형이 발생하면서 다양한 유전적 변이를 보이기 때문에 생식형태가 유사한 화본과 잔디의 경우 이들로부터 형질에 차이를 보였다 (Kang et al., 2008; O’Brien, 2012).

최근 한국잔디의 이용범위가 더욱 다양해지고 사용면적 도 확대됨에 따라 잔디 신품종 요구도가 증가되고 있다 (Choi and Yang, 2006). 이에 따라 국내 한국잔디의 자생 
지 현황조사 및 수집을 통해 신품종 개발에 대한 연구들 이 진행되고 있고(Bae et al., 2010), 근연종간에 교잡으로 중간형이 출현함에 따라 다양한 유전적 변이를 보이는 교 잡종 및 변이종 특성과 육종연구를 수행하여 신품종을 발 표하였다(Bae et al., 2013; Choi and Yang, 2004; Lee et al., 1997). 이와 같이 변이에 의한 형질에 차이를 보이는 계통의 선발이 품종개발의 주요 수단이 되고 있다(Chung et al., 2013).

현재 National Turfgrass Evaluation Program(NTEP) 에 등록된 한국잔디 품종은 11 종이며, 이중 1 종은 종자형으 로 개발되어 이용되고 있는 상태이다(www.ntep.org, 2010). 한국잔디는 주로 영양번식을 실시하여 왔으나 종자형 품 종의 등장으로 인해 그 이용도는 급속하게 늘어날 것으로 예상된다. 특히 'Zenith'와 같은 종자형 품종은 이미 국내 에 도입되어 이용되고 있는 상황이다.

따라서 본 연구에서는 국내에서 자생하고 있는 한국잔 디 유전자원 수집 및 유전자원을 이용하여 종자형 계통을 육성을 위해 한국잔디 종간의 종자 형태 및 변이 특성을 분석하여 육종에 직접 이용될 수 있는 유전적 변이 확대 를 위한 자료로 이용하고자 연구를 수행하였다.

\section{재료 및 방법}

\section{자생 한국잔디의 수집 및 형태적 특성}

자생 한국잔디 수집은 2010년 5월부터 2012년 9월까지 남 - 동해안 및 서해안, 도서, 내륙지역에서 수행되었다. 지역별로 한국잔디가 다양하게 분포되어 있을 것이라고 예상되는 곳을 시 · 군 단위로 나누어 자생하는 한국잔디 총 241개체를 수집하였다. 수집 시기는 생육이 왕성한 59월을 중심으로 하였으며, 수집 시간은 오전 10 시부터 오 후 3 시까지로 맑은 날 하였다. 한국잔디의 지역별 개체 수 집은 5 엽이 완전 전개된 것을 기준으로 초장, 엽폭과 잎 털의 유무, 종자의 형태, 종자의 크기, 생육환경별로 다양 한 변이를 보이는 것들을 수집하였다. 자생지 환경 분석 은 수집 당시의 자원상태, 수집지 환경, 지형 등을 조사하였다. 한국잔디별 분류는 Choi 등(1997)의 형태적 특성을 기
준으로 하여 엽폭 $5.0 \mathrm{~mm}$ 이상, 잎털이 많고, 종자길이 $3.5 \mathrm{~mm}$ 이하, 화서당 종자수 40 개 이상의 특성을 보이는 것을 들 잔디(Zoysia japonica Steud.)로 하였다. 해안지역에서 발견 되어 엽폭이 3.0-4.0 mm이고, 잎에 털이 없고, 종자길이 6.0-8.0 mm정도인 것을 갯잔디(Z. sinica Hance.)로 하고, 갯잔디와 유사한 생육을 보이나 엽폭이 넓고, 종자가 더 큰 것을 왕잔디(Z. machrostachya Franch. and Sav.)으로 구 분하였다. 초장이 짧고 엽폭 $2.0 \mathrm{~mm}$ 이하, 화서당 종자수 10-15개 특성을 보이는 것을 금잔디(Z. matrella [L.] Merr.) 로 하였다. 엽폭이 3.0-4.0 mm수준이며, 종자길이 3.0$6.0 \mathrm{~mm}$, 화서당 종자수 25-35개 정도인 것을 중지 (interspecific hybrid zoysia)로 구분하였다(Choi et al., 1997; Patton and Reicher, 2007).

\section{자생 한국잔디의 종자 형태 조사}

수집해 온 241개 한국잔디를 경남 진주 국립산림과학원 남부산림자원연구소 유전자원포장에 이식을 하였다. $1.3 \times 1.3 \mathrm{~m}^{2}$ 크기의 plot에 마사토를 깔아 수집해 온 잔디를 줄떼로 심고, 뿌리의 활착을 위해 하루에 1 번 관수를 하 였다. 수집지에서 가져 온 상태를 그대로 유지하기 위해 잔디깎기와 비료시비를 하지 않았다. 이식 후 유전자원포 장에서 개화되어 종자 임실이 완전한 상태의 15 개의 꽃대 를 뽑아 화서길이, 화서당 종자수, 종자길이, 종자폭, 종자 길이와 폭의 비를 조사하였다. 종자길이와 종자폭은 광학 현미경(Leica Microsystems Gmbh Wetzlar, Germany)으로 측정을 하여 종자길이와 폭의 비를 구하였다.

자료분석은 한국잔디의 조사된 종자의 형태적 형질을 $\mathrm{SAS}$ 프로그램(SAS 9.2)을 이용한 분산분석, 산포도, 판별 분석과 SPSS 통계프로그램을 이용해 유클리디안 제곱거 리로 군집분석을 수행하였다.

\section{결과 및 고찰}

\section{자생 한국잔디의 종자 형태 및 생태적 특성 분석}

한국잔디는 각 지역별로 241 개체 중 들잔디 79 개체, 갯 잔디 40 개체, 왕잔디 5 개체, 금잔디 18 개체, 중지 99 개체

Table 1. Morphological characteristics of seed of zoysiagrasses collected from South Korea.

\begin{tabular}{lccccc}
\hline \hline \multicolumn{1}{c}{ Species } & Spike width $(\mathrm{cm})$ & Seed length $(\mathrm{mm})$ & Seed width $(\mathrm{mm})$ & SL/SW ratio & No. of seed per spike \\
\hline Z. japonica & $3.0 \pm 0.2^{\mathrm{a}} \mathrm{b}$ & $3.5 \pm 0.4 \mathrm{c}$ & $1.4 \pm 0.1 \mathrm{a}$ & $2.4 \pm 0.2 \mathrm{c}$ & $44.9 \pm 4.0 \mathrm{a}$ \\
Z. sinica & $4.3 \pm 0.3 \mathrm{a}^{\mathrm{b}}$ & $7.6 \pm 0.4 \mathrm{a}$ & $1.5 \pm 0.1 \mathrm{a}$ & $5.0 \pm 0.3 \mathrm{a}$ & $21.3 \pm 1.5 \mathrm{c}$ \\
Z. macrostachya & $3.3 \pm 0.4 \mathrm{~b}$ & $7.0 \pm 0.3 \mathrm{a}$ & $1.5 \pm 0.1 \mathrm{a}$ & $4.6 \pm 0.2 \mathrm{a}$ & $21.2 \pm 3.1 \mathrm{c}$ \\
Z. matrella & $1.3 \pm 0.1 \mathrm{c}$ & $3.3 \pm 0.1 \mathrm{c}$ & $1.1 \pm 0.1 \mathrm{~b}$ & $3.1 \pm 0.2 \mathrm{~b}$ & $14.9 \pm 1.3 \mathrm{c}$ \\
Hybrid zoysia & $3.1 \pm 0.3 \mathrm{~b}$ & $4.4 \pm 0.5 \mathrm{~b}$ & $1.5 \pm 0.1 \mathrm{a}$ & $3.0 \pm 0.3 \mathrm{~b}$ & $33.1 \pm 5.3 \mathrm{~b}$ \\
\hline
\end{tabular}

${ }^{\mathrm{a}}$ Mean \pm Standard error.

${ }^{\mathrm{b}}$ Mean separation within columns by Duncan's multiple range test at $P=0.05$. 
를 수집하였다. 수집된 자생 한국잔디의 종자 형태적 특 성을 조사하여 형태 형질의 평균 특성을 살펴본 결과 화 서길이의 경우 갯잔디가 $4.3 \mathrm{~cm}$ 로 가장 길었고, 금잔디는 $1.3 \mathrm{~cm}$ 로 가장 짧은 특성을 보여 유의적인 차이가 있었다 (Table 1). 들잔디와 중지는 각각 $3.0 \mathrm{~cm}$ 와 $3.1 \mathrm{~cm}$ 로 그룹 간의 유의적인 차이가 없었다.

종자길이는 갯잔디가 $7.6 \mathrm{~mm}$ 로 가장 길었고, 금잔디와 들잔디는 3.3 과, $3.5 \mathrm{~mm}$ 로 가장 짧은 특성을 나타내었다 (Fig. 1). 중지는 $4.4 \mathrm{~mm}$ 로 들잔디, 금잔디와 유의적인 차이 를 보였다. 종자폭은 금잔디가 $1.1 \mathrm{~mm}$ 로 가장 좁았으며, 들 잔디와 왕잔디, 갯잔디, 중지 각각 1.4 와 $1.5 \mathrm{~mm}$ 로 유의적 인 차이가 없었다.

종자길이와 폭의 비는 갯잔디가 5.0 으로 긴 형태를 나 타내었고, 유의적인 차이는 없으나 금잔디와 중지는 각각 3.1 과 3.0 이고, 들잔디는 2.4 로 종간의 차이를 확인 할 수 있었다.

화서당 종자수는 들잔디가 44.9 개로 가장 많았으며, 다 음은 중지 33.1개로 유의적인 차이가 있었다. 갯잔디와 왕 잔디는 각각 21.3개와 21.2로 유의적인 차이는 없었으나, 금잔디의 경우 14.9 개로 가장 적은 수의 특성을 보여 유 의적인 차이가 나타났다.

Hong and Yeam (1985)은 한국잔디의 종간 교배 육종에 사용된 모본의 특성으로 들잔디, 금잔디, 갯잔디, 왕잔디 의 종자길이는 각각 $2.4,2.7,5.3,5.4 \mathrm{~mm}$ 로 보고하였다. Choi et al. (1997)은 종자형태 등을 이용하여 한국잔디류 의 형태적 특성을 조사한 결과 들잔디 유형은 화서당 종 자수가 45개로 가장 많은 특성을 나타내었다. 갯잔디 유 형은 종자길이가 $6.5 \mathrm{~mm}$ 로 긴 형태를 나타내었고, 중간적 인 특성을 보이는 교잡종은 종자길이 $3.8 \mathrm{~mm}$, 화서당 종 자수는 31 개로 나타났다고 하였는데 본 조사결과도 이들 의 보고와 유사한 특성을 보였다.

종자형태 연구는 많은 학자들에 의해 수행되어 왔으며, 속(genus)이나 절(section)의 분류학적 한계를 결정하는데
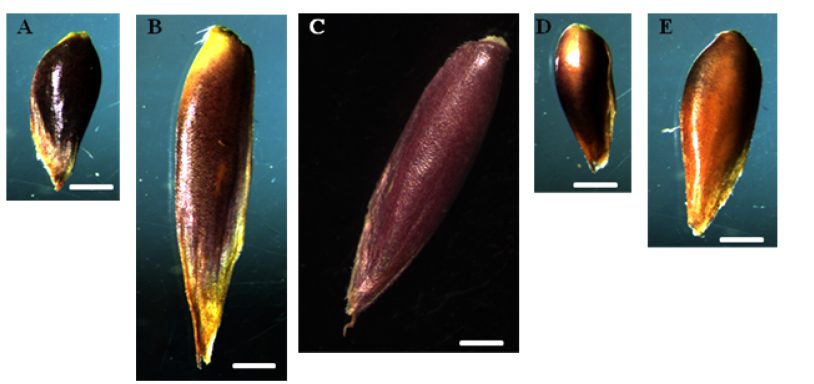

Fig. 1. Seed shape of zoysiagrasses collected from South Korea by light microscope. A: Zoysia japonica Steud.; B: Z. sinica Hance.; C: Z. machrostachya Franch. and Sav.; D: Z. matrella [L.] Merr.); E: interspecific hybrid zoysia. Unit: $\mathrm{mm}$.

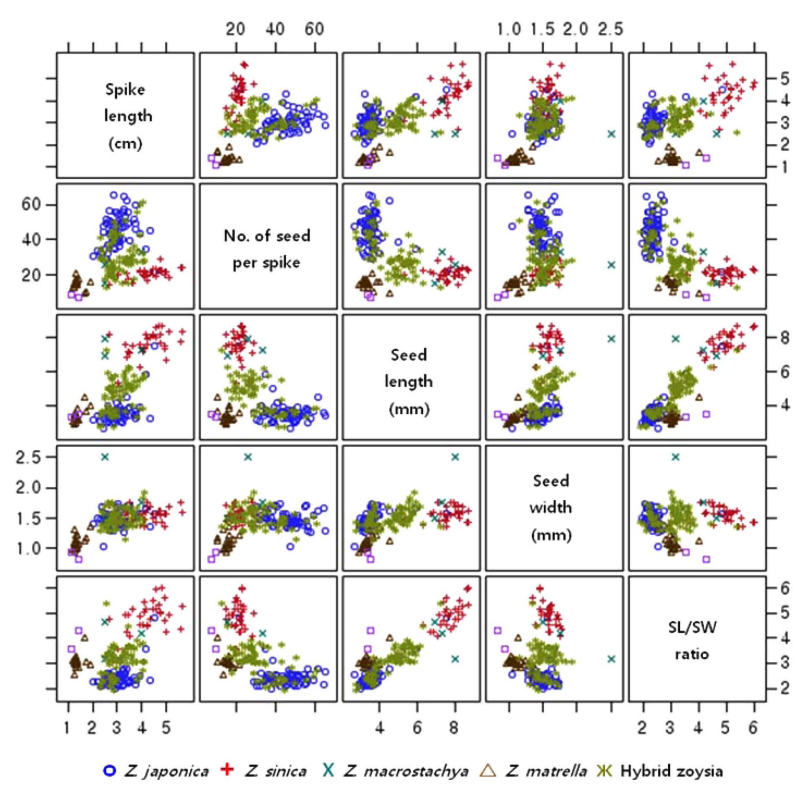

Fig. 2. Scatter plot matrix between the traits morphological characteristics of seed of zoysiagrasses collected from South Korea.

유용한 것으로 알려져 있다(Gil-ad, 1997). 이와 같이 종자 형태 형질을 이용하여 형질조합에 의한 산포도를 알아본 결과 화서길이 조합의 경우 화서길이와 화서당 종자수, 화 서길이와 종자길이, 화서길이와 종자폭, 화서길이와 종자 길이와 폭의 비의 두 형질을 동시에 고려한 산포도를 보 면 들잔디, 중지, 갯잔디와 왕잔디, 금잔디로 나뉘어졌으 며, 갯잔디와 금잔디는 비교적 명확히 구분이 되었다(Fig. 2). 화서당 종자수, 종자길이, 종자폭 조합에서도 유사한 경향을 나타내었다. 종자길이와 폭의 비 조합에서는 들잔 디가 일정한 범위 안에 분포하고 짧은 특성을 보인 반면 중지와 차이가 있었다. 금잔디와 중지가 중복되는 경향을 보였으나 비교적 일정한 범위로 모이는 것으로 나타났다.

한국잔디 자생지 생태적 특성을 파악하기 위해 수집지 의 환경을 조사한 결과 갯잔디와 왕잔디는 대부분 해안가 에서 야생상태로 자생하는 것으로 확인 되었다(Fig. 3a). 들잔디는 주로 야생형태로 $22.9 \%$ 는 해안가에서 자생하고 있었고, $21.7 \%$ 는 산림, $19.7 \%$ 는 저수지 주변의 제방에서 분포하고 있었고, $15.7 \%$ 는 경작지 주변, $13.3 \%$ 는 길가에 서 관찰되어 다양한 환경에서 생육하고 있었다. 중지도 야 생상태로 $34.6 \%$ 가 해안가로 비교적 많은 개체들이 분포 하고 있었고, $15.9 \%$ 는 산림, $14.4 \%$ 는 길가, $11.2 \%$ 는 경작 지에서 발견되어 중지 또한 들잔디와 같이 다양한 환경에 서 생육함을 알 수 있었다. 한국잔디류는 국내 자생지에 서 다양한 종류의 교잡종이 분포되고 있는 것으로 나타났 으며, Choi et al. (1997)의 결과와도 유사한 것으로 판단 


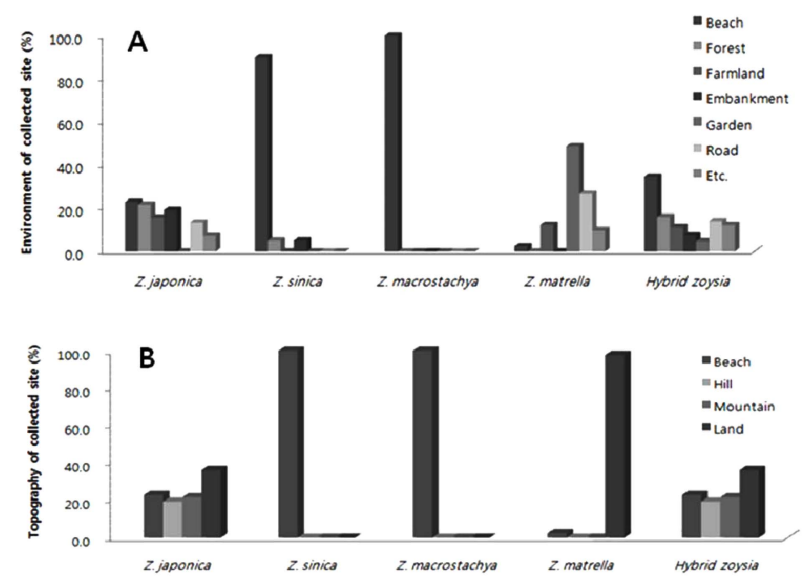

Fig. 3. Environment and topography of collected site of zoysiagrasses collected from South Korea. Sample was collected from May through September in 2010 (A) and 2012 (B).

된다. 반면에 금잔디는 $48.8 \%$ 대부분 농가 정원 근처, $26.8 \%$ 는 길가에서 식재 된 것이 확인 되었으며, 자연 상태에서 생육되는 것은 확인되지 않았다.

한국잔디의 수집 지형을 조사한 결과 들잔디는 전체 수 집 개체 중에서 $36.1 \%$ 가 평지나 들판에서 확인되었으며, $22.9 \%$ 는 해변, $21.7 \%$ 는 산, $19.3 \%$ 는 언덕에서 수집되어 다양한 지형에서 생육을 하고 있었다(Fig. 3b). 갯잔디와 왕잔디는 $100.0 \%$ 가 해변에서 분포를 하였다. 금잔디는 $97.6 \%$ 대부분 평지에서 확인되었고, 중지는 $32.7 \%$ 가 평 지, 다음으로는 $28.0 \%$ 가 해변, $23.4 \%$ 는 언덕, $15.9 \%$ 는 산 으로 들잔디와 같이 다양한 지형에서 분포하고 있었다.

이상의 결과에서 들잔디와 중지의 경우 광범위하게 분 포하여 다양한 환경과 생육특성을 보였으며, 갯잔디와 왕 잔디는 특정 자생지 환경으로 독특한 생존전략으로 생육 하고 있는 것으로 보아 종간의 생태적 특성이 상이함을 알 수 있었다. 이러한 서로 다른 생태적 특성으로 인해 비 교적 종간의 구별이 가능하였다.

\section{자생 한국잔디의 형태적 변이 특성}

형태적 형질은 유전자의 발현에 기본을 두고 있으며, 자 생지의 위도, 경도, 기상, 토양 등의 환경조건에 의하여 수 형, 잎, 꽃, 종자 등 형태적 특성의 지리적 변이가 존재하 고 있다는 것은 많은 연구들에서 보고되고 있는데(Kim, 1986; Lee and Kim, 1982), 이러한 집단의 유전적 다양성 을 분석하는데 외부형태의 변이분석과 DNA 등과 같은 분 자표지에 의해서 유전구조 양상을 구명하는 방법이 보편 화되어 있다(Kim et al., 2005). 이와 같은 외부 형태적 특 성을 통해 유전변이를 구명하기 위해서는 가능한 다양한 집단을 대상으로 각 집단의 변이를 명확히 대표할 수 있

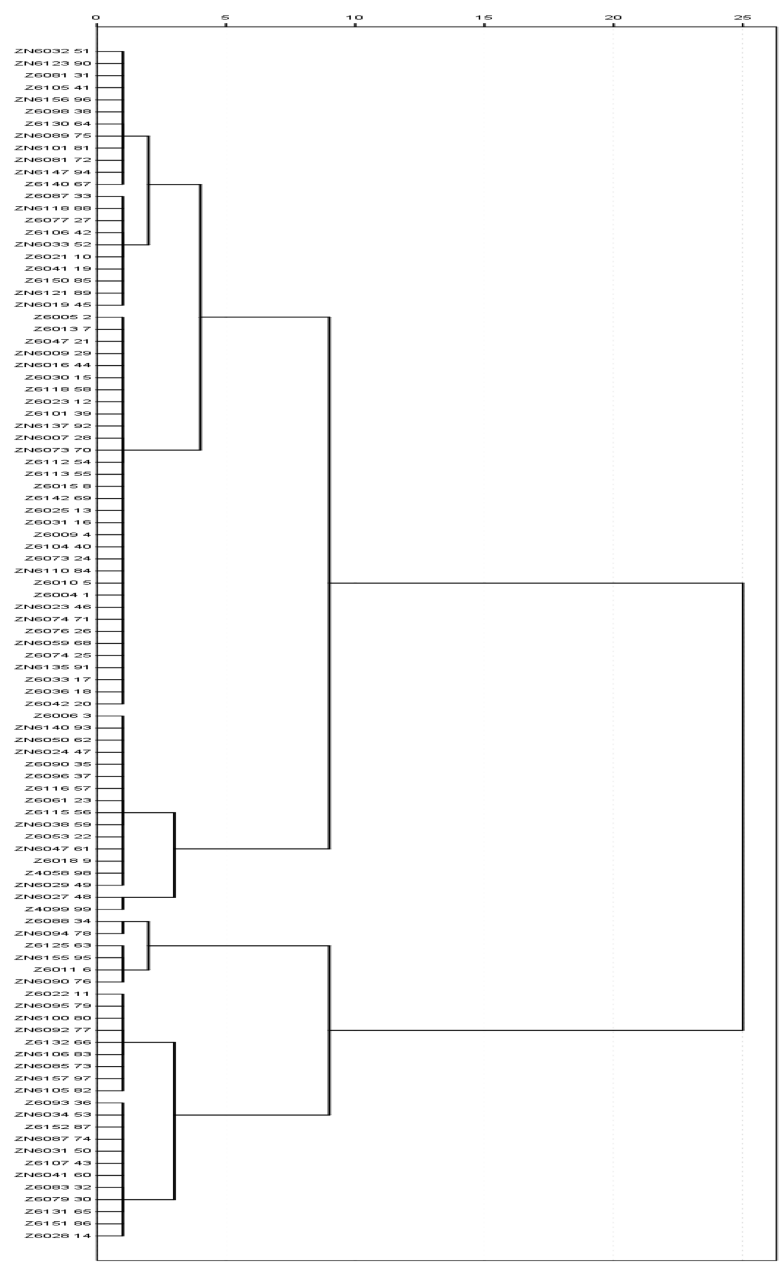

Fig. 4. Cluster dendrogram of interspecific hybrid zoysiagrasses based on Euclidean distance from seed morphological traits. The $\mathrm{Z}$ and $\mathrm{ZN}$ is collection code of zoysiagrasses native to South Korea.

는 형질을 선정하여야 하고, 집단간, 집단내 개체간의 변 이의 폭과 내용을 알고 집단간의 유연관계를 밝혀 주는 것이 중요하다(Song et al., 2000).

이와 같이 한국잔디 분류에 유용한 종자 형태 및 생태 적 특성을 통해 한국잔디의 종간의 차이를 확인 할 수 있 었고, 전체 수집종 241 개체 중에서 중간특성을 보이는 교 잡종 및 변이종으로 추정되는 중지가 99 개체로 $41 \%$ 수집 되어 미확인된 종으로 이에 대한 연구가 수행되어야 할 것으로 판단되었다.

따라서 수집된 중지의 종간 교잡 및 변이 정도를 추정 하고자 종자 형질을 이용하여 군집분석을 한 결과 갯잔디 형과 들잔디형으로 나뉘어졌으며, 각 형태별로 2 개의 군 으로 분류되었다(Fig. 4). 이는 Choi et al. (1997)의 들잔 디형과 갯잔디형 특성을 보이는 교잡종 및 변이종을 확인 한 결과와 유사하였고, 갯잔디와 들잔디 이들 간의 교잡 
Table 2. The characteristics of 2 groups classified using seed morphological traits of interspecific hybrid zoysiagrasses collected from South Korea.

\begin{tabular}{lcccc}
\hline \hline \multirow{2}{*}{ Traits } & \multicolumn{4}{c}{ Type of interspecific hybrid zoysiagrasses } \\
\cline { 2 - 5 } & \multicolumn{2}{c}{ Z. sinica type } & \multicolumn{2}{c}{ Z. japonicaa type } \\
\cline { 2 - 5 } & I & II & III & IV \\
\hline Spike length (cm) & $3.2 \pm 0.2^{\mathrm{b}}$ & $2.8 \pm 0.2$ & $3.6 \pm 0.7$ & $3.1 \pm 0.2$ \\
No. of seed per spike & $30.1 \pm 2.1$ & $17.5 \pm 1.4$ & $59.2 \pm 1.1$ & $45.8 \pm 1.7$ \\
Seed length (mm) & $4.6 \pm 0.4$ & $5.2 \pm 0.4$ & $3.3 \pm 0.2$ & $3.4 \pm 0.1$ \\
Seed width (mm) & $1.5 \pm 0.1$ & $1.5 \pm 0.1$ & $1.4 \pm 0.1$ & $1.4 \pm 0.1$ \\
SL/SW ratio & $3.1 \pm 0.2$ & $3.5 \pm 0.3$ & $2.5 \pm 0.1$ & $2.5 \pm 0.2$ \\
\hline
\end{tabular}

${ }^{a}$ Data were analyzed by SPSS using cluster analysis with Euclidean distance. The accessions were classified into 2 main based groups by seed morphological traits. $Z$. sinica type included group I and II, $Z$. japonica type included group III and IV.

${ }^{\mathrm{b}} \mathrm{Mean} \pm$ Standard error.

종들이 많이 형성되어 있다고 하였다(Hong and Yeam, 1985). 갯잔디형 I군의 경우 자생지 환경은 해안가 및 들잔디 가 자생하는 해안지역 산림과 길가에서 분포하여 대부분 해안가에 분포하는 II군에 비해 갯잔디와 들잔디의 교잡 이 된 형태특성을 나타내었다(Table 2). 화서당 종자수는 $\mathrm{I}$ 군 30.1 개, II군 17.5 개로 I군이 많았고, 종자길이는 I군 $4.6 \mathrm{~mm}$ 로 II군 $5.2 \mathrm{~mm}$ 보다 짧은 특성을 나타내었다. 현재 국내에서 사용중인 한국잔디는 들잔디와 갯잔디의 교잡종
이 대부분으로(Choi and Yang, 2005) I군은 화서당 종자 수 31 개, 종자길이 $3.8 \mathrm{~mm}$ 인 들잔디와 갯잔디의 중간적인 특성을 보이는 교잡종과 유사한 형태를 보였으며(Choi et $\mathrm{al}, 1997)$, II군은 전형적인 갯잔디와 유사하였다.

들잔디형 III군과 IV군의 자생지 환경은 해안이 아닌 내 륙의 산림, 길가, 경작지에 분포하였다. III군과 IV군 각각 화서당 종자수는 59.2개와 45.8개, 종자길이는 3.3 과 3.4 $\mathrm{mm}$, 종자길이와 폭의 비는 2.5 로 들잔디와 유사한 특성 을 나타내었다.

이상의 결과로 중지는 해안가, 산림, 길가, 경작지 등 광 범위하게 자생하고 있는 한국잔디와 종간교잡으로 자생지 환경에 따라 종자 형태에 있어 변이를 나타내는 중간종이 많이 분포하고 있었다. 이는 교잡 친화력이 있는 한국잔디 가(Forbes, 1952; Hong and Yeam, 1985) 서로 자연교잡되 어 연속적인 변이를 보이는 결과라고 추정되어지고(Choi et al., 1997), Christians과 Engelke (1994)가 Z. koreana는 들 잔디와 왕잔디의 교잡종이라고 추정한 것과 같이 자연 상 태에서 교잡된 변이들이 존재한다는 보고와 유사하였다. 이와 같이 국내에 많이 분포하고 있는 교잡종 및 변종들 은 생육속도가 빠르고 강한 내환경성 등 다양한 특성을 가 지고 있어 다수확 종자형 품종 등 목적에 부합되는 품종 개발을 위한 육종재료로 활용가치가 높다(Choi and Yang, 2005; Lee et al., 1997).

이와 같은 육종재료를 활용하여 효율적인 육종을 위해

Table 3. Interspecific distance index and discriminant probability of zoysiagrasses collected from South Korea by discriminant analysis.

\begin{tabular}{|c|c|c|c|c|c|}
\hline & Z. sinica & Z. matrella & Z. japonica & Z. macrostachya & Hybrid zoysia \\
\hline Z. sinica & $0.0^{\mathrm{a}}(84.9)^{\mathrm{b}}$ & $22.6(66.7)$ & 36.4 (88.9) & $6.0(100)$ & $19.0(63.4)$ \\
\hline Z. matrella & & 0.0 & 9.6 & 20.0 & 4.6 \\
\hline Z. japonica & & & 0.0 & 25.9 & 3.2 \\
\hline Z. macrostachya & & & & 0.0 & 12.5 \\
\hline Hybrid zoysia & & & & & 0.0 \\
\hline
\end{tabular}

${ }^{a}$ Interspecific distance index. Discriminant analysis were analyzed by SAS using seed morphological traits of zoysiagrasses.

${ }^{\mathrm{b}}$ Discriminant probability.

Table 4. Constant and discriminant function deduction of zoysiagrasses collected from South Korea by discriminant analysis.

\begin{tabular}{lccccc}
\hline \hline \multicolumn{1}{c}{ Var. } & Z. sinica & Z. matrella & Z. japonica & Z. macrostachya & Hybrid zoysia \\
\hline Constant & $-876.66^{\mathrm{a}}$ & -938.21 & -929.25 & -88.21 & -906.47 \\
Spike length & -0.5076 & -2.0754 & -2.9299 & -5.532 & -2.7381 \\
Seed length & -323.45 & -348.12 & -344.83 & -324.15 & -338.61 \\
Seed width & 1182.0 & 1274.0 & 1251.0 & 1194.0 & 1230.0 \\
SL/SW ratio & 482.988 & 512.041 & 503.149 & 484.224 & 497.274 \\
No. of seed spike & 0.16184 & 0.15069 & 0.2216 & 0.30309 & 0.18684 \\
\hline
\end{tabular}

${ }^{\text {a }}$ Discriminant analysis were analyzed by SAS using seed morphological traits of zoysiagrasses. 
주요 형질의 유전 양상의 이해와 유전자원의 수집 분류 및 평가가 중요하다. 이를 위해 자생 한국잔디 종별로 조 사된 종자 형질 특성을 이용하여 종간 유사성을 거리지수 로 구분한 결과 들잔디와 중지, 갯잔디와 왕잔디, 금잔디 와 중지가 유사한 집단으로 확인되었으며, 한국잔디의 판 별 확률은 갯잔디 $84.9 \%$, 금잔디 $66.7 \%$, 들잔디 $88.9 \%$, 중지 $63.4 \%$ 로 나타났다(Table 3). 한국잔디의 기본종과 교 잡종을 분류하기 위하여 판별함수를 이용한 유효인자의 계수와 식의 상수를 도출한 결과 화서길이, 종자길이, 종 자폭, 종자길이와 종자폭의 비율, 화서당 종자수가 유효한 인자로 확인되었다(Table 4). 이러한 결과는 자연상태에서 한국잔디의 종간교배 및 생육지의 입지적 특성 등 자생지 환경인자와 상관이 깊은 것으로 나타났으며, 판별함수를 이용하여 한국잔디 종간의 구별 가능성은 보였지만, 설명 력을 높이기 위한 지속적으로 변수 선택법 개발이 필요하 였다. 또한 한국잔디의 종간 해석은 비교적 질적인 유전 정보를 많이 함축하고 있는 종자의 형질을 이용하여 분류 를 하면 추정이 가능하지만 좀더 정확한 판단을 위해서는 분자학적 분석이 필요할 것으로 판단되었다.

\section{요 약}

본 연구는 국내에서 자생하고 있는 241 개체의 한국잔디 를 지역별로 수집하여 종자 형태적 형질을 조사했으며, 한 국잔디의 종자 형태적 특성 및 변이를 알아보고자 연구를 수행하였다. 수집된 한국잔디 241개체 중에서 중지가 99 개체로 $41 \%$ 이상이 수집되었으며, 다양한 형태의 종자 변 이를 보였다. 크게 갯잔디형과 들잔디형으로 두 개 그룹 으로 나뉘었으며, I과 II군은 화서당 종자수가 30.1개와 17.5 개, 종자길이는 4.6 과 $5.2 \mathrm{~mm}$ 으로 갯잔디형이 포함되었 고, III과 IV군은 화서당 종자수가 59.2개와 45.8개, 종자길 이는 3.3 과 $3.4 \mathrm{~mm}$ 으로 들잔디형 특성을 나타내었다. 정확 한 종간교잡의 정도를 파악하기 위해서는 추가적인 생육특 성 및 분자생물학적 연구가 필요하다고 판단되었다.

주요어: 종간교잡, 교잡종, 변이, 한국잔디

\section{Acknowledgement}

This study was supported by the Research Fellowship of the Korea Forest Research Institute in 2013.

\section{References}

Bae, E.J., Park, N.C., Lee, K.S., Lee, S.M., Choi, J.S., et al. 2010.
Distribution and morphology characteristics of native zoysiagarasses (Zoysia spp.) grown in South Korea. Kor. Turfgrass Sci. 24(2):97-105. (In Korean)

Bae, E.J., Lee, K.S., Han, E.H., Park, Y.B., Lee, S.M., et al. 2013. Morphological variation and characteristics of native mediumleaf type Zoysiagrass (Zoysia spp.) by site environment. Weed Turf. Sci. 2(2):184-190. (In Korean)

Choi, J.S. 1997. Breeding of zoysia in Korea. International Symposium of Zoysiagrass. Breeding. Dankook University. Korea. p.15-18 (Abstr.).

Choi, J.S., Ahn, B.J. and Yang, G.M. 1997. Distribution of native Zoysiagrasses (Zoysia spp.) in the South and West coastal regions of Korea and classification using morphological characteristics. Hort. Environ. Biotechnol. 38:399-407. (In Korean)

Choi, J.S. and Yang, G.M. 2004. Development of new hybrid cultivar 'Senock' in Zoysiagrass. Kor. Turfgrass Sci. 18(4):201-209. (In Korean)

Choi, J.S. and Yang, G.M. 2005. Comparison of growth rate and cold tolerance with basic species, commercial lines, and breeding lines of Zoysiagrass. Kor. Turfgrass Sci. 19:131-140. (In Korean)

Choi, J.S. and Yang, G.M. 2006. Sod Production in South Korea. Kor. Turfgrass Sci. 20:237-251. (In Korean)

Choi, D.K., Yang, G.M. and Choi, J.S. 2008. Flowering periods, genetic characteristics, and cross-pollination rate of Zoysia spp. in natural open-pollination. Kor. Turfgrass Sci. 22:13-24. (In Korean)

Christians, N.E. and Engelke, M.C. 1994. Choosing the right grass to fit the environment. pp. 99-113. In: Leslie, A.R. (Eds.). Integrated pest management for turf and ornamentals. CRC Press, Levis Publishers, NJ, USA.

Chung, S.J., Park, S.J., Kim, H.J., Yang, G.M., Choi, J.S., et al. 2013. RAPD-SCAR markers linked to medium-leaf zoysiagrass ecotypes. Weed Turf. Sci. 2(2):191-197. (In Korean)

Engelke, M.C., Murray, J.J. and Yeam, D.Y. 1983. Distribution, Collection and use of zoysiagrass in the far East, part II. Agronomy. p.125 (Abstr.).

Engelke, M.C. and Murray, J.J. 1989. Zoysiagrass breeding and cultivar development. The $6^{\text {th }}$ International Turfgrass Research Conference. pp.423-425 (Abstr.).

Forbes, I.J. and Ferguson, M.H. 1952. Effects of strain differences, seed treatment, and planting depth on seed germination of Zoysia spp. J. Amer. Soc. Agron. 40:725-732.

Gil-Ad, N.L. 1997. Systematics of Viola subsection BorealiAmericanae. Boissiera. 53:5-130. 
Hong, K.H. and Yeam, D.Y. 1985. Studies on interspecific hybridization in Korean lawngrass (Zoysia spp.). J. Kor. Soc. Hort. Sci. 26(2):169-178. (In Korean)

Kang, S.Y., Lee, G.J., Lim, K.B., Lee, H.J., Park, I.S., Chung, S.J., et al. 2008. Genetic diversity among Korean bermudagrass (Cynodon spp.) ecotypes characterized by morphological, cytological and molecular approaches. Mol. Cells 25:163-171.

Kim, K.N. 1986. Effects of photoperiod and temperature on the growth and flowering in Zoysia japonica Steud. MS Thesis. Seoul Nat'l. Univ., Korea

Kim, Y.J., Kim, K.C., Lee, B.S., Lee, G.Y., Cho, K.J., et al. 2005. The variation of leaf characteristics in 6 natural populations of Stewartia koreana Nakai. J. Kor. For. Soc. 94:446-452. (In Korean)

Lee, J.P., Kim, J.B., Im, S.H., Joo, Y.K., Kim, D.H., et al. 1997. Characteristics evaluation of a zoysiagrass line '232' in the tissue culture and field. Kor. Turfgrass Sci. 11(4):321-326. (In Korean)
Lee, K.Y. and Kim, H. K. 1982. The variation in needle characteristics of natural population of Abies koreana Wilson. J. Kor. For. Soc. 57: 39-44. (In Korean)

National Turfgrass Evaluation Program (NTEP). 2010. National zoysiagrass test. 2010 Progress Report NTEP. http://www. NTEP.org. (Accessed May 13, 2013)

O'Brien, P. 2012. Tifgreen bermudagrass: past, present, and future. USGA Green Sec. Record 50:1-4.

Patton, A.J. and Reicher, Z.J. 2007. Zoysiagrass species and genotypes differ in their winter injury and freeze tolerance. Crop Sci. 47:1619-2167.

Song, J.H., Park, M.H., Moon, H.K., Han, S.U., Yi, J.S., et al. 2000. The variation of leaf form of natural populations of Quercus variabilisin Korea. J. Kor. For. Soc. 89: 666-676. (In Korean)

Yu, T.Y., Yeam, D.I., Kim, Y.J. and Kim, S.J. 1974. Morphological studies on Korean lawn grasses (Zoysia spp.). J. Kor. Soc. Hort. Sci. 15(1):79-91. (In Korean) 